\title{
ESISIINST
}

\section{KAJIANILMU ADMINISTRASI}

Model Kepemimpinan dalam Reformasi Birokrasi Pemerintah (Rumsari Hadi Sumarto)

Total Quality Manajemen Dalam Penjaminan Mutu Pendidikan dan Upaya Peningkatannya (Rosidah)

Pengembangan Multimedia Pembelajaran Bahasa Inggris Kelas IV SD untuk Meningkatkan Hasil Belajar (Muslikhah Dwihartanti, Abdul Gafur)

Pemetaan Kompetensi, Tugas, dan Pekerjaan Sekretaris di Dunia Kerja (Suranto Aw, Rosidah,

\begin{tabular}{|c|c|c|c|c|c|}
\hline $\begin{array}{l}\text { Jurnal Prodi } \\
\text { P. ADP' FF. LNY }\end{array}$ & Vol, ХТा & No.l & Hal. $1-100$ & $\begin{array}{l}\text { Yogyakarta, } \\
\text { Fcbruti 2015 }\end{array}$ & $\begin{array}{c}\text { ISSN } \\
|412-| 131\end{array}$ \\
\hline
\end{tabular}




\section{REDAKSI}

Ketua Dewan Redaksi ～: Djihad Hisyam, M.Pd.

Sekretaris Redaksi $\quad$ : Siti Umi Khayatun Mardiyah, M.Pd.

Anggota Redaksi ～: Joko Kumoro, M.Si.

Muslikhah Dwihartanti, M.Pd.

Arwan Nur Ramadhan, M.Pd.

Sekretariat : Isti Kistiananingsih, S.Pd.

Alamat Redaksi $\quad$ : Prodi Pendidikan Administrasi Perkantoran

Fakultas Ekonomi

Universitas Negeri Yogyakarta

Kampus Karangmalang Yogyakarta 555281

Telp. (0274) 586168 Ext. 583 Fax. (0274) 554902

Website : http://journal.uny.ac.id/index.php/efisiensi

Email: efisiensi@uny.ac.id

Redaksi menerima tulisan masalah ilmu administrasi. Redaksi berhak menyingkat dan mengedit tulisan yang akan dimuat tanpa mengubah substansi isinya. Hak cipta dilindungi oleh undang-undang. 


\title{
PEMETAAN KOMPETENSI, TUGAS, DAN PEKERJAAN SEKRETARIS DI DUNIA KERJA
}

\author{
Suranto Aw, Rosidah, Joko Kumoro \\ suranto@uny.ac.id,ros_adp@yahoo.co.id,jokokum@uny.ac.id
}

\section{ABSTRAK}

Penelitian ini bertujuan untuk mendapatkan gambaran mengenai: (1) kompetensi kerja; (2) bidang tugas; dan (3) jenis-jenis pekerjaan profesi sekretaris di dunia kerja. Penelitian ini merupakan penelitian deskriptif, memfokuskan pada usaha melacak informasi dari para praktisi administrasi perkantoran atau sekretaris, dan memetakan hasil pelacakan tersebut secara sistematis. Subjek penelitian ini adalah praktisi sekretaris di berbagai instansi pemerintah maupun swasta. Teknik analisis data yang digunakan dalam penelitian ini adalah analisis data secara deskriptif dengan menggunakan tabel distribusi frekuensi dan histogram, serta dilengkapi penjelasan secara naratif. Hasil penelitian menunjukkan: (1) Terdapat tiga kategori kompetensi sekretaris yaitu: kompetensi umum, kompetensi inti, dan kompetensi khusus (tambahan); (2) Bidang tugas sekretaris mencakup: komunikasi, administrasi perkantoran, mengelola keuangan, dan legal (hukum); dan (3) Jenis-jenis pekerjaan yang secara rutin dikerjakan seorang sekretaris mencakup: bertelepon, berkomunikasi secara interpersonal, menggunakan media komunikasi, menerima tamu, mengelola keluhan pelanggan, mengoperasikan komputer, mengatur otomatisasi pekerjaan kantor, mencari informasi lewat internet, mengurus surat, mengelola arsip, mengatur perjalanan dinan pimpinan, mengatur penggunaan perlengkapan kantor, mengatur pertemuan/rapat, membuat laporan, mengelola kas kecil, dan mengurus pekerjaan di bidang legal (hukum).

\section{Kata kunci: Pemetaan, Tugas, Pekerjaan, Sekretaris}

Pemetaan Kompetensi, Tugas, dan Pekerjaan Sekretaris di Dunia Kerja (Suranto Aw, Rosidah, Joko Kumoro) 


\section{Pendahuluan}

Kemajuan perekonomian dan teknologi dalam era globalisasi semakin me-nuntut tersedianya Sumber Daya Manusia (SDM) yang berkualitas dan kompeten di segala sektor usaha. Penyediaan SDM berkualitas tersebut, terkait dengan upaya agar sebuah institusi mampu menghadapi persaingan yang semakin tajam. Dengan demikian setiap institusi perlu menempuh upaya nyata dalam rangka peningkatan kemampuan SDM sehingga memiliki kompetensi pada bidangnya masing-masing. Apabila sebuah institusi gagal dalam membekali kemampuan tenaga kerjanya, maka diduga akan mengalami penurunan kinerja, kalah dalam kompetisi, dan mengalami marginalisasi tenaga kerja lokal oleh tenaga kerja eksternal.

\section{Untuk menyiapkan SDM} yang bermutu sesuai dengan tuntutan kebutuhan pasar kerja atau dunia usaha dan industri di era globalisasi ini, perlu adanya hubungan timbal balik antara dunia usaha/industri dengan lembaga pendidikan dan pelatihan. Salah satu bentuk hubungan timbal balik tersebut adalah pihak dunia usaha/industri diharapkan dapat merumuskan standar kualifikasi SDM yang diinginkan, untuk menjamin kesinambungan usaha atau industri tersebut. Sedangkan lembaga pendidikan dan pelatihan akan meng-gunakan standar tersebut sebagai acuan dalam mengembangkan program pendidikan dan kurikulum. Dengan demikian capaian pembelajaran para lulusan yang dihasilkan oleh lembaga pendidikan memiliki relevansi dengan tuntutan kompetensi di pasar kerja. Selanjutnya diperlukan sinergi dengan birokrasi dengan harapan pihak birokrat akan menggunakannya sebagai acuan dalam merumuskan kebijakan dalam pengembangan SDM secara makro.

Kompetisi global telah banyak menuntut tersedianya tenaga yang memiliki kecakapan dan keterampilan melaksanakan tugas dan pekerjaan di dunia kerja. Seiring dengan perkembangan teknologi informasi dan komunikasi, dunia kerja juga membutuhkan tersedianya angkatan kerja yang memiliki kualifikasi keterampilan kerja 
berbasis pengetahuan teknologi. Secara rasional apabila seseorang tidak memiliki kualifikasi keterampilan sesuai dengan kebutuhan dunia kerja, maka akan dengan mudah tersisih dari kompetisi.

Perkembangan tuntutan kompetensi dan kualifikasi tersebut sangat terasa pula dalam bidang kesekretariatan. Tugas seorang sekretaris tidak lagi dibatasi dalam bidang tatausaha saja, namun dewasa ini menjadikan tugas sekretaris menjadi lebih luas serta beragam. Jika dahulunya sekretaris lebih dikenal sebagai juru tulis atau juru ketik, saat ini kemajuan berbagai aspek menuntut profesi seorang sekretaris didukung kemampuan bekerja secara profesional, yaitu memiliki pengetahuan, sikap, dan keterampilan yang memadai sesuai dengan tuntutan kualifikasi dan kompetensi bidang pekerjaannya.

Secara umum, masyarakat meng-artikan sekretaris sebagai sebuah profesi administratif yang bersifat asisten atau mendukung. Pendapat ini merujuk kepada sebuah pekerja kantor yang tugasnya ialah melaksanakan perkerjaan rutin, tugas-tugas administratif, atau tugas-tugas pribadi dari atasannya. Dari segi asal kata, istilah sekretaris berasal dari kata secretum dalam bahasa Latin yang berarti rahasia. Dengan demikian sesuai asal katanya, istilah sekretaris adalah orang, pegawai, atau karyawan yang diberi tugas dan pekerjaan berhubungan dengan masalah rahasia perusahaan/kantor. Sekretaris adalah orang, pegawai, atau karyawan yang diberi tugas dan pekerjaan yang berhubungan dengan masalah rahasia negara atau perusahaan. Menurut Kamus Umum Bahasa Indonesia, sekretaris adalah orang atau pegawai yang diserahi pekerjaan tulismenulis. Ignatius Wursanto (2006: 2) menerangkan, sekretaris adalah pembantu pimpinan. Sutarto (1997: 4) mengatakan sekretaris adalah pegawai kantor.

Sosok seorang sekretaris kurang lebih sebagai petugas yang diharapkan dapat membantu pimpinan dalam penanganan administrasi kantor. Sebagai pembantu pimpinan, sekretaris harus memiliki kemampuan yang memadai, sehingga semua tugas dan tanggung jawab sekretaris 
dapat terorganisir dengan baik, dan pada gilirannya kegiatan menajemen organisasi perusahaan atau perkantoran dapat berjalan dengan lancar.

Dengan mencermati perkembangan teknologi maupun perkembangan kegiatan organisasi saat ini, maka menjadi calon sekretaris yang profesional merupakan suatu tantangan sekaligus peluang yang strategis. Seorang calon sekretaris harus memiliki kemampuan dan kapasitas yang memadai. Sekretaris memegang peran penting dalam menentukan atau mempengaruhi berhasil tidaknya tujuan dalam kegiatan perkantoran, perusahaan, atau organisasi. Oleh karena itu sekretaris diharuskan untuk dapat menjalankan tugastugas secara efektif dan efisien mulai dari tugas ringan hingga tugas yang bersifat penting dan mendesak.

Untuk dapat menghasilkan lulusan yang mampu mengisi formasi sekretaris profesional dengan kualifikasi keterampil-an sesuai dengan kebutuhan dunia kerja, maka diperlukan informasi faktual karakteristik kompetensi, tugas, dan pekerjaan sekretaris di dunia kerja. Sampai saat ini, di dunia kerja baik di instansi pemerintah maupun swasta belum ada kesamaan dan belum dilakukan standardisasi deskripsi tugas dan pekerjaan untuk sekretaris. Namun demikian, sesuai dengan kewajiban organisasi untuk memberikan pelayanan terbaik kepada publik, kebutuhan akan pelayanan sekretaris bukannya tidak ada, meskipun tentu saja berbeda dari ekspektasi para pimpinan atau manajemen organisasi, perusahaan, dan perkantoran.

Pemetaan adalah proses penggambaran objek kajian tertentu dengan menggunakan cara dan/atau metode tertentu sehingga didapatkan hasil berupa sebuah gambaran baik secara naratif maupun visual. Dalam kamus bahasa Indonesia pemetaan atau visualisasi adalah pengungkapan suatu gagasan atau perasaan dengan menggunakan gambar, tulisan, peta, dan grafik. Sementara itu Kitty O. Locker (2004:27), mengatakan bahwa "peta adalah alat relasi (relational tools) yang menyediakan informasi antar hubungan entitas yang dipetakan."

Pemetaan Kompetensi, Tugas, dan Pekerjaan Sekretaris di Dunia Kerja

(Suranto Aw, Rosidah, Joko Kumoro) 
Definisi pemetaan yang dirumuskan dalam kamus bahasa Indonesia menekankan pada pengungkapan perasaan dalam bentuk gambar, tulisan, peta, dan grafik. Definisi ini menekankan produk atau output dari peta. Sedangkan Locker lebih menekankan proses kegiatan pemetaan. Kedua pendapat ini tidak berbeda melainkan saling melengkapi, karena sebuah produk atau output pemetaan dihasilkan melalui proses. Berdasarkan dua pengertian tersebut dapat dinyatakan bahwa pemetaan merupakan sebuah proses yang memungkinkan seseorang mengenali elemen pengetahuan serta konfigurasi, dinamika, ketergantungan timbal balik dan interaksinya.

Dalam penelitian ini pengetahuan yang dipetakan adalah tugas dan pekerjaan administrasi perkantoran (sekretaris) di dunia kerja. Pemetaan tugas dan pekerjaan sekretaris digunakan untuk keperluan manajemen pembelajaran sekretaris itu sendiri, mencakup definisi sekretaris, keputusan menyangkut aktivitas yang berkaitan dengan teknologi, kinerja, etika, tugas, pekerjaan berbasis pengetahuan serta pemrograman pendidikan dan pelatihan. Output dari kegiatan pemetaan ini adalah naskah deskriptif naratif dan tabulasi informasi yang menunjukkan hubungan antar elemen tugas dan pekerjaan sekretaris. Dengan demikian dalam penelitian ini pemetaan tugas dan pekerjaan sekretaris diwujudkan dalam bentuk narasi dan tabulasi, sehingga terealisir pemataan ilmu pengetahuan atau knowledge mapping, yaitu untuk bidang keahlian administrasi perkantoran (sekretari). Dalam penelitian ini pemetaan ditentukan berdasarkan hasil analisis data yang diperoleh dari data primer bersifat empiris di dunia kerja dan data sekunder dari kajian pustaka yang relevan.

Tugas seorang sekretaris bukan hanya sebagai pembantu pimpinan dalam penanganan korespondensi (surat me-nyurat), menerima tamu, tata warkat (kearsipan), mempersipkan jadwal kerja pimpinan, dan menyelenggarakan rapat. Sektretaris juga mengemban tugastugas kreatif yang dari waktu ke waktu selalu mengalami perubahan dalam hal ragam dan 
karakteristiknya. Oleh karena itu aktivitas penelitian untuk mengidentifikasi dan mendeskripsikan tugas dan pekerjaan sekretaris di dunia kerja merupakan langkah penting, sehingga dapat diperoleh indikator yang jelas tentang tugas dan pekerjaan yang secara riil diperlukan oleh dunia kerja.

Masalah yang melatarbelakangi pentingnya dilakukan penelitian ini adalah bahwa kompetensi lulusan Prodi D3 Administrasi Perkantoran (Sekretari) belum sepenuhnya sinkron dengan kompetensi yang dibutuhkan oleh dunia kerja, baik di lembaga pemerintah maupun swasta. Hal ini disebabkan oleh terjadinya perkembangan yang cepat dalam bidang informasi dan teknologi, sehingga dunia kerja menuntut tersedianya tenaga profesional yang mampu melaksana-kan berbagai tugas dan pekerjaan. Perkembangan tuntutan kompetensi di dunia kerja tersebut, belum sepenuhnya direspon oleh lembaga pendidikan yang menyiapkan caloncalon tenaga kerja.

Dalam penanganan kegiatan kesekretariatan telah terjadi pergeseran karakteristik tugas dan pekerjaan sekterais, sehingga hal ini harus diantisipasi oleh kampus. Seiring dengan dilaksanakannya penyusunan dan pengembangan kurikulum baru, maka diperlukan informasi dari para praktisi sekretaris, maupun para pengguna lulusan sekretari yaitu para pimpinan kantor dan perusahaan. Informasi tersebut sebagai bahan pertimbangan bagi pe-ngelola program studi untuk melakukan pemetaan tugas dan pekerjaan sekretaris dan pada giliran berikutnya untuk keperluan sinkronisasi kurikulum dengan kebutuhan dunia kerja. Dengan sinkron-isasi kurikulum akan dapat dikondisikan lulusan yang mampu menyiapkan perangkat tugas dan pekerjaan sesuai dengan kebutuhan di dunia kerja.

Banyak faktor yang menyebabkan kurangnya kecakapan melaksanakan pekerjaan tertentu, antara lain karena kompetensi lulusan belum sesuai dengan kebutuhan user (dunia kerja). Jika kondisi ini dibiarkan terus berlangsung, maka harapan untuk menghasilkan lulusan yang mempunyai kompetensi unggul dalam menangani tugas dan 
pekerjaan sekretaris tidak akan berhasil seperti yang di-harapkan.

\section{Metode}

Penelitian ini merupakan penelitian deskriptif, memfokuskan pada usaha melacak informasi dari para praktisi administrasi perkantoran (sekretaris), pelaku pendidikan di bidang administrasi perkantoran (sekretari), serta studi pustaka selanjutnya mendeskripsikan hasil pelacakan, dan memetakan hasil pelacakan tersebut secara sistematis.

Subjek penelitian ini adalah praktisi sekretaris di berbagai instansi pemerintah maupun swasta dan para pelaku pendidikan di bidang kesekretarisan (administrasi perkantoran). Penentuan subjek penelitian sebagai responden adalah dengan teknik insidental dipadukan teknik snow ball. Teknik insidental dimaksudkan untuk mendapatkan seorang sampel starter yang secara kebetulan ditemui saat penelitian. Diawali dari seorang sekretaris dan pelaku pendidikan sekretari sebagai sampel starter, kemudian diperoleh informasi tentang alamat dan nomor kontak para sekretaris dan pelaku pendidikan berikutnya.

Intrumen yang digunakan dalam penelitian ini adalah kuesioner yang diisi oleh responden. Kuesioner terdiri dari beberapa pertanyaan yang bersifat tertutup, dan ada pula yang terbuka. Untuk kuesioner tertutup, dari setiap pertanyaan sudah disediakan alternatif jawaban sehingga responden tinggal memberikan tanda contreng pada jawaban yang tersedia. Sedangkan kesioner terbuka, memberi kesempatan kepada responden untuk mengemukakan jawaban secara terperinci.

Teknik analisis data yang digunakan dalam penelitian ini adalah analisis data secara deskriptif. Jalaluddin Rakhmat (1998: 22) mengemukakan, analisis deskriptif bertujuan untuk melukiskan secara sistematis fakta atau karakteristik populasi tertentu atau bidang tertentu secara faktual dan cermat. Analisis deskriptif dalam penelitian ini ditempuh dengan menggunakan teknik tabulasi distribusi frekuensi dan 
histogram, serta dilengkapi dengan penjelasan secara naratif. Adapun langkah-langkah analisis data adalah sebagai berikut: (1) Instrumen yang telah terisi oleh responden diperiksa kelengkapannya. Instrumen yang tidak lengkap dianggap tidak memenuhi syarat untuk dianalisis; (2) Dibuat buku kode sebagai upaya untuk memandu peneliti mengkonversi data kualitatif menjadi kuantitaif (numerik); (3) Menyusun Data view dan Variable view sebagai aturan main sistem data numerik dari semua variabel; (4) Melakukan input data, dari instrumen ke tabel induk data penelitian; (5) Analisis data secara deskriptif dengan bantuan program SPSS 11 for Windows; dan (6) Membuat tabel distribusi frekuensi, dan narasi seperlunya.

\section{Hasil dan Pembahasan \\ Hasil}

Kompetensi kerja ialah kemampuan kerja setiap individu yang mencakup aspek pengetahuan, keterampilan dan sikap kerja yang sesuai dengan standar yang ditetapkan. Berdasarkan data hasil studi pustaka menunjukkan adanya berbagai pola dalam membuat klasifikasi kompeten-si dalam bidang administrasi perkantoran (kesekretarisan). Pada penelitian ini disusun empat klasifikasi untuk memperoleh tanggapan responden, yaitu mencakup: (1) Umum, Inti, Khusus;

(2) Pokok, Tambahan;

Instruktif, Kreatif; dan

Lainnya dengan maksud untuk menampung pendapat responden yang tidak sejalan dengan salah satu opsi klasifikasi di atas. Hasil analisis terhadap pola klasifikasi kompetensi sekretaris disajikan pada tabel 1 sebagai berikut.

Tabel 1. Kompetensi Kerja Sekretaris

\begin{tabular}{|c|c|c|c|}
\hline Kompetensi & Frekuensi & Persentase & $\begin{array}{c}\text { Persentase } \\
\text { Kumulatif }\end{array}$ \\
\hline $\begin{array}{c}\text { Umum, } \\
\text { Inti, Khusus }\end{array}$ & 27 & 77,1 & 77,1 \\
\hline $\begin{array}{c}\text { Pokok, } \\
\text { Tambahan }\end{array}$ & 5 & 14,3 & 91,4 \\
\hline $\begin{array}{c}\text { Instruksi, } \\
\text { Kreatif }\end{array}$ & 2 & 5,7 & 97,1 \\
\hline Lainnya & 1 & 2,9 & 100,0 \\
\hline Total & 35 & 100,0 & \\
\hline
\end{tabular}

Tabel 1 tersebut menjelaskan bahwa responden terbanyak berpendapat pengklasifikasian kompetensi di bidang administrasi perkantoran (kesekretarisan) mengikuti opsi

Pemetaan Kompetensi, Tugas, dan Pekerjaan Sekretaris di Dunia Kerja

(Suranto Aw, Rosidah, Joko Kumoro) 
pertama (umum, inti, dan khusus), yaitu mencapai 27 orang $(77,1 \%)$. Hal ini mengindikasikan pendeskripsian kompetensi administrasi perkantoran dalam penelitian ini menggunakan pola: kompetensi umum, kompetensi inti, dan kompetensi khusus. Dengan demikian dalam penelitian ini unit-unit kompetensi dalam bidang pekerjaan administrasi perkantoran dapat dikelompokkan kedalam 3 (tiga) kategori, yaitu : kelompok umum, kelompok inti, dan kelompok khusus.

Kelompok umum mencakup unit-unit kompetensi yang berlaku dan d-butuhkan pada hampir semua sub-sub bidang keahlian, misal yang berkait dengan berkomunikasi di tempat kerja dan menggunakan komputer. Kelompok utama/inti, mencakup unit-unit kompetensi yang berlaku dan dibutuhkan hanya untuk spesifik sub bidang keahlian (stream) administrasi perkantoran (kesekretarisan) dan merupakan unit yang wajib (compulsary) sub bidang keahlian administrasi

perkantoran. Kelompok khusus/pilihan mencakup unit-unit kompetensi yang dapat ditambahkan kedalam sub bidang keahlian administrasi perkantoran, sebagai pelengkap, pendukung, dan bersifat pilihan.

Dari berbagai literatur, tugas seorang sekretaris (administrasi perkantoran) dapat diklasifikasikan ke dalam dua kategori, yaitu tugas rutin dan insidental. Tugas rutin adalah tugas yang dijumpai dan dikerjakan setiap hari, tanpa mencari atau menunggu waktu khusus dan tanpa me-nunggu perintah dari pimpinan untuk melakukannya. Sedangkan tugas insidental, merupakan tugas spontan yang disesuaikan dengan kebutuhan dan tuntutan situasi dan kondisi faktual. Berdasarkan kajian literatur, telah dapat diidentifikasi berbagai tugas di bidang layanan kesekretarisan atau administrasi perkantoran. Berbagai bidang tugas tersebut mencakup: (1) komunikasi dan kehumasan; (2) pelayanan prima; (3) otomatisasi dan teknologi informasi; (4) administrasi perkantoran atau kesekretaris-an; (5) pengelolaan keuangan; (6) etika dan pengembangan diri; (7) K3 perkantoran; (8) hukum; dan 
Jurnal Efisiensi - Februari 2015 - Vol XIII No. 1 - ISSN 1412-1131 - Hal. 51-69

Pemetaan Kompetensi, Tugas, dan Pekerjaan Sekretaris di Dunia Kerja (Suranto Aw, Rosidah, Joko Kumoro) 
(9) administrasi sarana dan kerja. Hasil analisis terhadap prasarana.

Masing-masing bidang tugas tersebut dimintakan penilaian kepada responden mengenai relevansinya dengan kebutuhan dan tuntutan di dunia jabaran bidang tugas dalam bidang administrasi perkantoran (kesekre-tarisan) selengkapnya dapat disimak dalam tabel 2 berikut ini.

Tabel 2. BidangTugas Sekretaris

\begin{tabular}{|c|l|c|c|c|c|}
\hline \multirow{2}{*}{ No } & \multirow{2}{*}{$\begin{array}{l}\text { Bidang } \\
\text { Tugas Sekretaris }\end{array}$} & \multicolumn{4}{|c|}{ Tanggapan Resonden } \\
\cline { 3 - 6 } & \multicolumn{2}{|c|}{ Relevan } & \multicolumn{2}{c|}{ Tidak Relevan } \\
\hline 1 & Kumlah & Persentase & Jumlah & Persentase \\
\hline 2 & Komunikasi dan kehumasan & 33 & 94,28 & 2 & 5,72 \\
\hline 3 & Pelayanan prima & 24 & 68,57 & 11 & 31,43 \\
\hline & $\begin{array}{l}\text { Otomatisasi dan teknologi } \\
\text { informasi }\end{array}$ & 33 & 94,28 & 2 & 5,72 \\
\hline 4 & $\begin{array}{l}\text { Administrasi perkantoran } \\
\text { atau kesekretarisan }\end{array}$ & 29 & 82,85 & 6 & 17,15 \\
\hline 5 & Pengelolaan keuangan & 32 & 91,42 & 3 & 8,58 \\
\hline 6 & Etika dan pengembangan diri & 33 & 94,28 & 2 & 5,72 \\
\hline 7 & K3 perkantoran & 25 & 71,42 & 10 & 28,58 \\
\hline 8 & Hukum & 15 & 42,86 & 20 & 57,14 \\
\hline 9 & $\begin{array}{l}\text { Administrasi sarana dan } \\
\text { prasarana }\end{array}$ & 22 & 62,85 & 13 & 37,15 \\
\hline
\end{tabular}

Komunikasi merupakan salah tugas yang dituntut pada hampir semua bidang pekerjaan. Tugas komunikasi pada hakikatnya adalah untuk menjalin interaksi guna menyelesaikan pekerjaan, seperti mengaplikasikan keterampilan dasar komunikasi dan berkomunikasi melalui media tertentu. Sedangkan kehumasan adalah tugas kelem- bagaan guna menjalin hubungan baik dengan publik, baik internal maupun eksternal. Sebagian besar responden $(94,28 \%)$ menyatakan bidang tugas komunikasi relevan dengan kebutuhan dunia kerja. Melalui analisis data hasil wawancara, diperoleh simpulan bahwa menurut responden, bidang tugas komunikasi dan kehumasan termasuk dalam kom-

Pemetaan Kompetensi, Tugas, dan Pekerjaan Sekretaris di Dunia Kerja (Suranto Aw, Rosidah, Joko Kumoro) 
petensi kelompok umum. Pada dasarnya kompetensi kelompok umum mencakup unit-unit kompetensi yang berlaku dan dibutuhkan pada hampir semua sub-sub bidang keahlian, dan semua sub bagian ketugasan di sebuah organisasi. Dengan demikian tugas komunikasi dan kehumasan merupakan salah satu tugas yang bersifat umum dan terjadi di semua bagian atau sub bagian dalam sebuah organisasi kerja.

\section{Pelayanan prima me-} rupakan kompetensi dasar yang harus dimiliki untuk memberikan pelayanan yang terbaik kepada pelanggan/kolega dalam seluruh proses kegiatan pekerjaan yaitu bekerj-asama dengan kolega/ pelanggan dan memberikan pelayanan kepada pelanggan. Penelitian ini mencoba menjaring pendapat responden mengenai relevansi bidang tugas pelayanan prima bagi tuntutan dunia kerja dewasa ini. Tabel di atas menjelaskan bahwa sebagian besar responden $(68,57 \%)$ menyatakan relevan dengan tuntutan dunia kerja.

Otomatisasi kantor merupakan peng-gunaan mesin atau teknologi berbasis komputer untuk memudahkan penyelesaian berbagai bidang tugas dan pekerjaan kantor. Pada saat ini, perangkat teknologi sudah menjadi kebutuhan penting guna mendukung pencapaian kinerja kantor secara lebih optimal. Penggunaan teknologi di perkantoran semakin dibutuhkan mengingat bahwa setiap kantor senantiasa ingin mencapai peningkatan kinerja dan produktivitas. Pekerjaan perkantoran yang semula dikerjakan secara manual, sebagian besar sudah digantikan dengan melibatkan penggunaan mesin-mesin kantor berbasis komputer. Oleh karena itu, tanggapan sebagian besar responden $(94,28 \%)$ menyatakan relevan dengan tuntutan dunia kerja.

Bidang tugas kesekretarisan (administrasi perkantoran) terdiri dari unit-unit kompetensi bidang administrasi, yang berhubungan dengan tugas administrasi perkantoran mulai dari proses pembuatan, penerimaan, pengumpulan, pendataan dan penggandaan serta pendokumentasian data/ informasi dan lainnya yang diperoleh unit kerja untuk suatu tindak lanjut kebijakan. Bidang

Pemetaan Kompetensi, Tugas, dan Pekerjaan Sekretaris di Dunia Kerja (Suranto Aw, Rosidah, Joko Kumoro) 
tugas ini merupakan kompetensi inti yang menjadi indikator profesionalisme seorang praksisi administrasi pekantoran (kesekretarisan). Distribusi tanggapan responden menunjukkan mayoritas menyetujui bidang tugas administrasi perkantoran relevan dengan tuntutan dunia kerja, sebagaimana dinyatakan oleh $82,85 \%$ responden.

Etika dan pengembangan diri merupakan komitmen untuk bertugas secara professional dan berkaitan dengan kemampuan pengelolaan pekerjaan secara efektif dan efisien. Dalam melaksanakan setiap pekerjaan/ tugas sesuai dengan jabatan dan jenjang klasifikasi dalam pencapaian kompetensinya, perlu dipandu norma etika meliputi: sikap, disiplin, loyalitas, kejujuran, kesetiaan, dan tanggung jawab terhadap setiap pekerjaan yang dikerjakannya dengan memiliki pengetahuan, keterampilan yang sesuai dengan materi bidang kegiatannya. Hasil analisis terhadap tanggapan responden, menunjukkan adanya kecenderungan sebagian besar responden $(94,28 \%)$ setuju bidang tugas etika dan pengembangan diri ini relevan dengan tuntutan dunia kerja.

Tugas mengelola keuangan adalah unit tugas yang bersifat sebagai pelengkap dari kompetensi inti yang diperlukan untuk melaksanakan pekerjaan administrasi perkantoran. Untuk mengemban tugas mengelola keuangan ini, setidaknya praktisi administrasi perkantoran dituntut memiliki kemampuan menyusun laporan kas kecil. Laporan kas kecil terdiri dari unit-unit kompetensi untuk mendukung pekerjaan pengelolaan keuangan pada lingkup pengelolaan keuangan berskala kecil dan hanya digunakan untuk unit kerja yang bersangkutan sesuai dengan peraturan yang diterapkan pada unit kerja dan atau perusahaan yang bersangkutan. Sebaran pendapat responden menunjukkan kecenderungan bahwa bidang tugas mengelola keuangan relevan dengan tuntutan dunia kerja, sebagaimana dinyatakan oleh $91,42 \%$ responden.

Bidang tugas K3 Perkantoran adalah unit kompetensi pelengkap yang di-perlukan bagi tenaga kerja bidang Administrasi Perkantoran untuk melaksanakan

Pemetaan Kompetensi, Tugas, dan Pekerjaan Sekretaris di Dunia Kerja (Suranto Aw, Rosidah, Joko Kumoro) 
pekerjaan dengan memperhatikan prosedur Keselamatan, Keamanan, dan Kesehatan (K3) kerja di kantor. Hasil analisis data menunjukkan sebagian besar responden $(71,42 \%) \quad$ setuju bidang tugas $\mathrm{K} 3$ ini relevan dengan tuntutan dunia kerja.

Bagi praktisi administrasi perkantoran (sekretaris), bidang tugas legal adalah unit kompetensi pelengkap dari kompetensi inti yang diperlukan untuk melaksanakan pekerjaan yang berhubungan dengan penanganan pekerjaan di bidang hukum. Bidang tugas ini terkait dengan kemampuan dan pemahaman fungsi legal (hukum) bagi setiap dokumen administrasi. Distribusi tanggapan responden menunjukkan tugas legal relevan dengan tuntutan dunia kerja, yakni 42,86\%, sisanya $57,14 \%$ menyatakan tidak relevan.

Pekerjaan seorang praktisi administrasi perkantoran (sekretaris) merupakan aktivitas yang dominan dilaksanakan dalam ke- sibukan sehari-hari. Berdasarkan hasil penelitian jenis-jenis pekerjaan sekretaris atau administrasi perkantoran yang relevan dengan kebutuhan dunia kerja mencakup: (1) bertelepon; (2) berkomunikasi secara interpersonal; (3) menggunakan media komunikasi; (4) menerima tamu; (5) mengelola keluhan pelanggan; (6) mengatur pekerjaan kantor; (7) mencari informasi lewat internet; (8) mengurus surat; (9) mengelola arsip; (10) mengatur perjalanan pimpinan; (11) mengatur pertemuan; (12) membuat laporan; (13) mengelola kas kecil; dan (14) mengurus dokumen legal.

Pembahasan

Pada pembahasan ini, pemetaan mengenai kompetensi, tugas, dan pekerjaan administrasi perkantoran (sekretaris) dikemukakan dalam suatu pola pemetaan yang sederhana. Hasil pemetaan tersebut secara lengkap dipaparkan melalaui tabel 3 sebagai berikut 
Tabel 3. Pemetaan Kompetensi, Tugas, dan Pekerjaan Sekretaris

\begin{tabular}{|c|c|c|}
\hline Kompetensi & Tugas & Pekerjaan \\
\hline \multirow[t]{7}{*}{ Umum } & \multirow[t]{3}{*}{ Komunikasi } & Bertelepon \\
\hline & & Berkomunikasi secara interpersonal \\
\hline & & Menggunakan media komunikasi \\
\hline & \multirow[t]{2}{*}{ Pelayanan Prima } & Menerima tamu \\
\hline & & $\begin{array}{l}\text { Mengelola keluhan dan komplain } \\
\text { pelanggan }\end{array}$ \\
\hline & \multirow{2}{*}{$\begin{array}{l}\text { Otomatisasi dan teknologi } \\
\text { informasi }\end{array}$} & Mengoperasikan komputer \\
\hline & & $\begin{array}{l}\text { Mengatur otomatisasi pekerjaan } \\
\text { kantor }\end{array}$ \\
\hline \multirow[t]{7}{*}{ Inti } & \multirow{7}{*}{$\begin{array}{l}\text { Administrasi perkantoran } \\
\text { (kesekretarisan) } \\
\text { Etika, pengembangan diri, dan K3 }\end{array}$} & Mencari informasi lewat internet \\
\hline & & Mengurus surat (mail handling) \\
\hline & & Mengelola arsip \\
\hline & & Mengatur perjalanan dinas pimpinan. \\
\hline & & $\begin{array}{l}\text { Mengatur penggunaan perlengkapan } \\
\text { dan peralatan kantor }\end{array}$ \\
\hline & & Mengatur pertemuan/rapat \\
\hline & & Membuat laporan \\
\hline \multirow{2}{*}{$\begin{array}{l}\text { Khusus } \\
\text { (pelengkap) }\end{array}$} & Mengelola Keuangan & Mengelola kas kecil \\
\hline & Legal (Hukum) & $\begin{array}{l}\text { Mengurus domuken di bidang legal } \\
\text { (hukum) }\end{array}$ \\
\hline
\end{tabular}

Berdasarkan pemetaan dari hasil analisis data pada penelitian ini, kompetensi untuk bidang administrasi perkantoran (sekretaris) dapat dibagi menjadi 3 (tiga) kategori, yaitu kompetensi umum, kompetensi inti (utama), dan kompetensi tambahan. Kompetensi umum mencakup unit-unit kompetensi yang be- rlaku secara umum, dalam arti dibutuhkan pada hampir semua sub-sub bidang keahlian, dan dibutuhkan pula pada hampir semua instansi atau perusahaan. Kompetensi yang termasuk kategori umum, misalnya yang berkait dengan berkomunikasi di tempat kerja dan menggunakan

Pemetaan Kompetensi, Tugas, dan Pekerjaan Sekretaris di Dunia Kerja (Suranto Aw, Rosidah, Joko Kumoro) 
computer, sudah tentu dibutuhkan oleh semua lembaga.

Kompetensi pada kelompok inti atau utama, merupakan kompetensi yang bersifat dominan dan menjadi ciri utama kompetensi di bidang layanan administrasi perkantoran (sekretaris). Kompetensi inti mencakup unit-unit kompetensi yang berlaku dan dibutuhkan hanya untuk spesifik sub bidang keahlian (stream) administrasi perkantoran dan merupakan unit yang wajib dikuasai (compulsary) para praktisi administrasi perkantoran. Kompetensi pelengkap mencakup unit-unit kompetensi yang dapat ditambahkan kedalam usaha memperkuat layanan di bidang administrasi perkantoran, dan sifatnya sebagai pelengkap.

Berdasarkan pemetaan dari hasil analisis data pada penelitian ini, tugas di bidang administrasi perkantoran (sekre-taris) dapat dibagi menjadi 6 (enam) kategori sebagai berikut: 1) Komunikasi merupakan tugas dasar yang harus dimiliki dalam berinteraksi untuk menyelesaikan pekerjaan, seperti mengaplikasikan keterampilan dasar komunikasi dan berkomunikasi melalui media lainya; 2) Pelayanan prima merupakan tugas yang harus dikerjakan untuk memberikan pelayanan yang terbaik kepada pelanggan/kolega dalam seluruh proses kegiatan pekerjaan yaitu bekerjasama dengan kolega/ pelanggan dan memberikan pelayanan kepada pelanggan; 3) Otomatisasi dan teknologi informasi merupakan tugas yang harus dikerjakan oleh karena setiap kegiatan Administrasi Perkantoran berdasarkan pada teknologi informasi seperti mengoperasikan komputer/perangkat keras dan menggunakan peralatan kantor; 4) Administrasi perkantoran, tugas inti pada bidang keahlian/pekerjaan Administrasi Perkantoran/Kesekretarisan dan merupakan unit-unit yang wajib (compulsary) dari sub bidang keahlian/pekerjaan administrasi perkantoran/kesekretarisan dengan tingkat pengetahuan dan keterampilan tertentu. Bidang tugas ini dalam pelaksanaannya tidak dapat dilepaskan dari tugas menjaga etika, pengembangan diri, dan K3 kesekretarisan; 5) Mengelola kas kecil, terdiri

Pemetaan Kompetensi, Tugas, dan Pekerjaan Sekretaris di Dunia Kerja (Suranto Aw, Rosidah, Joko Kumoro) 
dari unit-unit kompetensi untuk mendukung pekerjaan pengelolaan keuangan pada lingkup pengelolaan keuangan berskala kecil dan hanya digunakan untuk unit kerja yang bersangkutan sesuai dengan peraturan yang diterapkan pada unit kerja dan atau perusahaan yang bersangkutan; 6) Legal (hukum), adalah unit kompetensi pelengkap dari kompetensi inti yang diperlukan untuk melaksanakan pekerjaan yang berhubungan dengan dan atau di bidang penanganan pekerjaan di bidang hukum.

Profesi sekretaris mengabdikan tugasnya pada sekorsektor organisasional, korporat, maupun publik. Setiap organisasi itu pasti memberlakukan adanya standar baik berupa tuntutan unjuk kerja, nilai-nilai, norma, maupun etika. Dengan demikian pola perilaku dan cara bertugas melaksanakan profesi sekretaris akan diwarnai oleh segala macam standar yang terjelma ke dalam kebiasaan yang berlaku di dalam sistem organisasi. Selain itu, setiap organisasi pastilah mempunyai harapan, kepentingan, tujuan, keinginan, cita-cita. Jadi dapat dikatakan bahwa aturan dan harapan menjadi input yang menggerakkan perkembangan kompetensi, tugas, dan pekerjaan sekretaris. Kalau dibahas lebih tajam, adanya harapan perlu dipandu dengan aturan. Harapan saja tanpa ada aturan, cenderung mendorong organisasi korporat serakah, melakukan berbagai hal untuk mengejar keuntungan sendiri dan mengabaikan hak orang lain. Kitty O. Locker ( 2004: 297) mengatakan bahwa sekretaris sebagai profesi, dalam operasionalnya dipengaruhi oleh norma sosial, budaya, politik, hukum, dan ekonomi yang bersumber dari national culture, organizational culture, dan personal culture.

\section{Kesimpulan}

Berdasarkan hasil yang diperoleh dari analisa data dan pembahasan dapat disimpulkan sebagai berikut: 1) Pemetaan kompetensi administrasi perkantoran (sekretaris) menjadi tiga kategori, yaitu: kompetensi umum, kompetensi inti, dan kompetensi khusus (tambahan);

Pemetaan Kompetensi, Tugas, dan Pekerjaan Sekretaris di Dunia Kerja (Suranto Aw, Rosidah, Joko Kumoro) 
2) Pe-metaan tugas di bidang layanan administrasi perkantoran (sekretaris) mencakup: komunikasi, pelayanan prima, otomatisasi dan teknologi informasi, administrasi perkantoran, mengelola keuangan, dan legal (hukum); 3) Pemetaan pekerjaan di bidang layanan administrasi perkantoran (sekretaris) mencakup: bertelepon, berkomunikasi secara interpersonal, menggunakan media komunikasi, menerima tamu, mengelola keluhan pelanggan, mengoperasikan komputer, mengatur otomatisasi pekerjaan kantor, mencari informasi lewat internet, mengurus surat, mengelola arsip, mengatur perjalanan dinan pimpinan, mengatur penggunaan perlengkapan kantor, mengatur pertemuan/ rapat, membuat laporan, mengelola kas kecil, dan mengurus pekerjaan di bidang legal (hukum).

\section{Daftar Pustaka}

Ignatius Wursanto. (2006). Kompetensi sekretaris profesional. Yogyakarta: Andi offset.

Kitty O. Locker. (2004). Business and communication.

Ohio:

McGraw Hill Irwin.

MG. Hartiti Hendrato \& FX.

Tulusharyono.

(2003).

Menjadi sekretaris

profesional. Jakarta : PPM

Rosidah \& Ambar Teguh S. (2005). Menjadi sekretaris professional di kantor yang efektif. Yogyakarta: Gava media.

Rumsari Hadi Sumarto \& Lukas Dwiantara. (2000). Sekretaris professional. Yogyakarta: Kanisius.

Said Saggaf. (2014) Pelayanan Fungsi Administrasi

Perkantoran Modern. Jurnal Administrare. Vol 1 No 1 Tahun 2014.

Saiman. (2002). Manajemen sekretaris. Jakarta: Ghalia Indonesia.

Soemadi Surjabrata, 1980, Psikologi Pendidikan, Yogyakarta: Raka Press Sutarto. (1997). Sekretaris dan tata warkat. Yogyakarta: Gadjah Mada University Press.

Pemetaan Kompetensi, Tugas, dan Pekerjaan Sekretaris di Dunia Kerja (Suranto Aw, Rosidah, Joko Kumoro) 


\section{Biodata}

Dr. Suranto, Aw, M.Pd., M.Si. merupakan Ketua Jurusan Prodi. Ilmu Komunikasi Fakultas Ilmu Sosial Universitas Negeri Yogyakarta. Riwayat pendidikan S1 ditempuh di UGM tahun 1986 pada bidang Ilmu Komunikasi, pendidikan S2 diselesaikan di IKIP Yogyakarta pada bidang ilmu PEP pada tahun 1996, dan pendidikan S2 diselesaikan di UNPAD pada bidang Ilmu Komuniasi pada tahun 2000. Studi S3 diselesaikan di PPs UNY pada bidang ilmu PEP tahun 2013.

Dra. Rosidah, M.Si., merupakan Dosen Tetap di Juruasn Pendidikan Administrasi FE UNY dan saat ini terpilih kembali menjadi Ketua Program Studi Administrasi Perkantoarn D3 Periode 2015-2019. Menyelesaikan S1 di IKIP Yogyakarta tahun 1987 dan menempuh studi S2 di UGM bidang Ilmu Administrasi Negara tahun 2000.
Drs. Joko Kumoro, M.Si. merupakan dosen tetap di Jurusan Pendidikan Administrasi Perkantoran FE UNY dan saat ini aktif menjabat sebagai Ketua Jurusan Pendidikan Administrasi Perkantoran FE UNY. 


\section{KEMENTERIAN RISET, TEKNOLOGI, DAN PENDIDIKAN TINGGI \\ UNIVERSITAS NEGERI YOGYAKARTA \\ FAKULTAS EKONOMI \\ JURUSAN PENDIDIKAN ADMINISTRASI}

Alamat: Karangmalang Yogyakarta, 55281, Telp. (0274) 586168 Ext. 583 Fax. (0274) 554902

Website : http://journal.uny.ac.id/index.php/efisiensi | e-mail : efisiensi@uny.ac.id

\section{RAMBU-RAMBU TEKNIS PENULISAN UNTUK EFISIENSI}

1. Tulisan merupakan suatu kajian ilmiah tentang masalah administrasi dan belum pernah dipublikasikan pada media lain.

2. Tulisan disusun dengan sistematika ilmiah mencakup unsur-unsur : (a) judul, (b) abstrak (c) pendahuluan tentang masalah yang dibahas, (d) tinjauan secara teoritis dan pembahasan, (e) perspektif baru yang diajukan, (f) kesimpulan, (g) daftar pustaka dan, (h) biodata.

3. Judul tulisan dibuat secara singkat namun menggambarkan substansi isi, sebaiknya tidak lebih dari sepuluh kata.

4. Abstrak yang menggambarkan intisari keseluruhan isi tulisan, disusun secara naratif, kurang lebih 100 kata, diketik satu spasi.

5. Di bawah abstrak ditulis kata kunci.

6. Penunjukan sumber acuan dilakukan dengan cara sebagai berikut:

a. Azhar Kasirn (1998) menyatakan bahwa

b. Senada dengan pendapat Azhar Kasim (1998) bahwa

c. ... dikemukakan pula oleh Kristiadi (Azhar Kasim, 1998) kebijakan swastanisasi merupakan

7. Penulisan daftar pustaka:

a. Azhar Kasim. (nama, tahun, halaman). Pengukuran Efektivitas dalam Organisasi. Jakarta: Lembaga Penerbit FEUI \& PusatAntar Universitas Ilmu-ilmu Sosial.

b. March, J.G. dan J.P.Olsen (ed). 1990. Ambiguity and Choice in Organization. Oslo Universitetsforlaget.

8. Biodata penulis dalam narasi, memuat nama lengkap, gelar, tempat dan tanggal lahir, pendidikan terakhir, nama lembaga dan karya ilmiah yang relevan dengan masalah yang dibahas.

9. Nama penulis dan alamat dicantumkan di bawah judul, tanpa gelar.

10. Panjang tulisan 10 sampai 15 halaman kuarto ketik spasi ganda (MS Word, Arial 10), diterima redaksi dalam bentuk print-out dua eksemplar dan CD. 


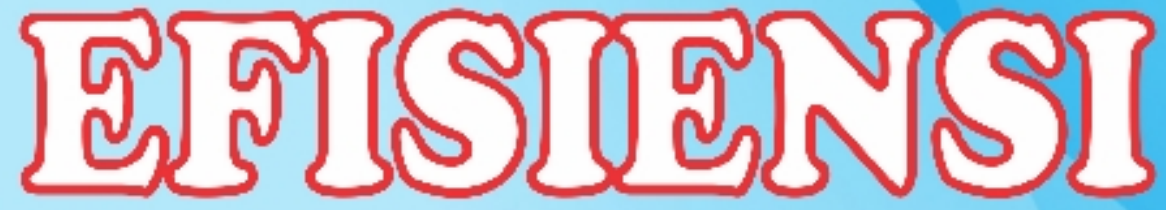

KAJIANILMU ADMINISTRASI

Volume XIII, Nomor 1, Februari 2015

ISSI: 1412-1131

Program Studi Pendidikan Administrasi Perkantoran Fakultas Ekonomi Universitas Negeri Yogyakarta 